\title{
Marketing of meat sheep with intensive finishing in southern state of Mexico
}

\author{
Jaime Mondragón-Ancelmo • Juvencio Hernández-Martínez • Samuel Rebollar-Rebollar • \\ Abdelfattah Zeidan Mohamed Salem • Rolando Rojo-Rubio • \\ Ignacio Arturo Domínguez-Vara • Anastacio García-Martínez
}

Received: 18 March 2014 / Accepted: 15 August 2014 / Published online: 4 September 2014

(C) Springer Science+Business Media Dordrecht 2014

\begin{abstract}
The objective of the present study was to quantify the marketing margins of cold sheep carcass and barbacoa meat in the southern state of Mexico. Data were obtained from the production chain links (production, industrialization, and marketing) where the marketing margins were calculated along with the benefit/cost $(\mathrm{B} / \mathrm{C})$ ratio. In the absolute marketing margin of the final consumer price per kilogram of carcass meat, the producer obtained US $\$ 2.7 / \mathrm{kg}(47 \%)$ of the utilities, while the intermediaries obtained US\$3.1/ $\mathrm{kg}$ (53\%). Considering the final cooked product in barbacoa (typical dish), the margin was US\$6.3/kg (29\%) for the producer and US\$15.2/ $\mathrm{kg}(71 \%)$ for the intermediaries. The B/C ratio was 1.0,1.1,2, and 1.3 for the producer, stocker, butcher, and barbacoa seller, respectively. It is concluded that the best marketing channel for the producer was the producerstocker-processor (butcher and barbacoa seller). The highest marketing margin was for the intermediaries followed by the producer. The order of importance of the $\mathrm{B} / \mathrm{C}$ kilogram ratio of meat was for the butcher first, then barbacoa seller, and lastly stocker and producer.
\end{abstract}

Keywords Barbacoa $\cdot$ Hair sheep $\cdot$ Marketing channels and margins $\cdot$ Meat $\cdot$ Production costs

J. Mondragón-Ancelmo $(\bowtie) \cdot J$. Hernández-Martínez $\cdot$

S. Rebollar-Rebollar · R. Rojo-Rubio $\cdot$ A. García-Martínez

Centro Universitario UAEM Temascaltepec, Universidad Autónoma

del Estado de México, Temascaltpec, Mexico

e-mail: jaimemond_01@hotmail.com

A. Z. M. Salem • I. A. Domínguez-Vara

Facultad de Medicina Veterinaria y Zootecnia, Universidad

Autónoma del Estado de México, Toluca, Mexico

\section{Introduction}

Sheep production in Mexico has been considered as a productive activity because of the availability of native grasses and forages. However, there is a serious challenge in the integration of the production chain, processing, and marketing of the sheep value. Currently, the demands of the market are unknown due to lack of price information and the characteristics or quality of the products (i.e., breed, sex, age, weight, type of food) (Teferra et al. 2011). These are some of the problems that have halted the development of the production, industrialization, and marketing of sheep meat, skins, and wool in Mexico.

Diverse studies have characterized the productive process and marketing channels of sheep meat in Mexico, as well as the appropriation of the marketing margins on the part of the hair sheep meat producers (Mondragón-Ancelmo et al. 2012; Hernández-Martínez et al. 2013). However, little has been documented with respect to the appropriation of the marketing margin in hair sheep under intensive finishing conditions. It is possible that due to the present price of hair skin (US\$6.5) vs. wool skin (US\$2.7) and the high costs of the cereal grains used in feedlots, changes could be made for the marketing margins.

The objective of the current study was to quantify the marketing margins of hair sheep meat under intensive finishing conditions, in order to increase the capacity of each sector of appropriating the final value, so that in the future, production and marketing strategies for the product can be found.

\section{Materials and methods}

The work was carried out in 2013 in the productive sector of the southern state of Mexico and in the industrialization and 
marketing links of the municipality of Capulhuac, state of Mexico. Using the data of primary sources and interviews with informants of the different sectors, the principal marketing channels were identified (Cochran 1984).

Ten farmers dedicated to the production of Katahdin hair sheep were enrolled in the study. Monitoring was carried out during the process of production, industrialization, and marketing productive management: sale of live sheep from the farm, transport to the in situ slaughter, transformation or industrialization to meat and by-products, sale of carcasses and raw by-products to the barbacoa sellers or consumer (barbacoa, traditional dish in Mexico, where the sheep meat and viscera with diverse ingredients and water are placed in a clay or metal recipient and covered with maguey leaves placed in a hole in the ground, previously heated to red hot, for cooking and seasoning), transformation of carcass and byproducts to barbacoa, and sale of the barbacoa to the final consumer. The following made it possible to obtain indicators of the productive behavior: waste in transport, weight and commercial yield of carcass and raw by-products, weight and yield of carcass and by-products cooked in barbacoa, weight and yield of the barbacoa meat to tacos, production costs of the live and processed sheep meat, and sale prices of the products and by-products. With the above information, calculations were done to determine costs, prices, and marketing margins of the hair sheep meat.

\section{Productive response indicators}

To a sample of 100 sheep of a mean initial weight of $37.7 \pm$ $3.16 \mathrm{~kg}$ of the Katahdin breed, DM/day was measured, along with gain of LW/day, and final LW; feed conversion was estimated (CDM/GLW), and production cost was determined to produce $1 \mathrm{~kg}$ of live meat, cold carcass, and cooked meat (Table 1).

\section{Value of waste per transport}

The difference was calculated of final mean live weight 45.77 $\pm 3.53 \mathrm{~kg}$, of 100 sheep with live farm sale, minus the weight at arrival to in situ slaughter. The distance of transport was $110 \mathrm{~km}$ (approx. $3 \mathrm{~h}$ ) from the southern portion of the state to Capulhuac (Table 2).

\section{Coefficient of market yield of cold carcass meat}

This value was determined with the weight of cold carcass/ slaughter weight $\times 100$. The rest of the components of the fifth quarter of the sheep were weighed, red viscera, green viscera; later, yield was calculated (weight of the component $\times 100 / \mathrm{LW}$ at slaughter) (Table 2).

Yield coefficient of cold carcass meat and raw viscera (pancita), to cook meat and pancita in barbacoa (pancita,
Table 1 Productive behavior

\begin{tabular}{llll}
\hline Productive response & Unit of measure & Value & $\mathrm{SD}$ \\
\hline Initial live fattening weight & $\mathrm{kg}$ & 37.4 & 3.2 \\
Fattening period & $\mathrm{day}$ & 30 & - \\
Daily weight gain & $\mathrm{kg} /$ day & 0.3 & 0.1 \\
Total weight gain & $\mathrm{kg}$ & 8.4 & 2.2 \\
Final live weight & $\mathrm{kg}$ & 45.8 & 3.5 \\
DM consumption & $\mathrm{kg} /$ sheep/day & 1.5 & 0.2 \\
Total DM consumption & $\mathrm{kg}$ & 44.7 & - \\
Feed conversion & $\mathrm{kg}$ & 5.3 & 1.2 \\
\hline
\end{tabular}

$S D$ standard deviation

prepared with green and red viscera along with the components of the reproductive apparatus) (Table 3). These data were registered at the end of the cooking process of the meat in barbacoa of a sample of $10(10 \%)$ sheep carcasses at the home of the barbacoyero (a person who prepares the sheep meat in barbacoa); next, yield was calculated (weight of the barbacoa meat $\times 100 /$ weight of cold carcass).

Number of tacos per kilogram of meat cooked

In 55 barbacoa stands, three tacos with barbacoa meat were purchased from each stand (a taco is when the barbacoa meat is wrapped with a tortilla made with a corn or wheat tortilla). An Ohaus precision scale with a maximum capacity of $610 \mathrm{~g}$ was used for weighing. Next, the number of tacos per

Table 2 Weight of the components of the carcass and fifth quarter

\begin{tabular}{llll}
\hline Concept & $\begin{array}{l}\text { Unit of } \\
\text { measure }\end{array}$ & Value & $\mathrm{SD}$ \\
\hline Farm sale & $\mathrm{kg}$ & 45.8 & 3.5 \\
Slaughter or market & $\mathrm{kg}$ & 43.3 & 3.4 \\
Waste at slaughter & $\mathrm{kg}$ & 2.5 & 0.1 \\
Warm carcass & $\mathrm{kg}$ & 22.0 & 2.2 \\
Cold carcass & $\mathrm{kg}$ & 21.5 & 2.2 \\
Waste of hot carcass & $\mathrm{kg}$ & 0.5 & 0.2 \\
Market yield of carcass & $\%$ & 49.8 & 2.5 \\
Head & $\mathrm{kg}$ & 2.1 & 0.2 \\
Feet & $\mathrm{kg}$ & 1.0 & 0.1 \\
Sheepskin & $\mathrm{kg}$ & 3.9 & 0.5 \\
Blood & $\mathrm{kg}$ & 1.6 & 0.2 \\
Testicles & $\mathrm{kg}$ & 0.8 & 0.1 \\
Red viscera (lungs, heart, liver) & $\mathrm{kg}$ & 1.8 & 0.3 \\
Full green viscera (reticulum, psalterium, & $\mathrm{kg}$ & 8.0 & 1.0 \\
$\quad$ rumen, abomasum, small and large intestine) & & & \\
Empty green viscera (without feces) & $\mathrm{kg}$ & 2.7 & 0.4 \\
Content of green viscera (feces) & $\mathrm{kg}$ & 5.2 & 0.8 \\
Green and red viscera and testicles (pancita) & $\mathrm{kg}$ & 5.3 & 1.2 \\
\hline
\end{tabular}


Table 3 Weight of carcass meat and pancita in barbacoa

\begin{tabular}{llll}
\hline Concept & Unit of measure & Value & $\mathrm{SD}$ \\
\hline Carcass with bone in barbacoa & $\mathrm{kg}$ & 15.8 & 1.6 \\
Waste of carcass with bone in barbacoa & $\mathrm{kg}$ & 5.7 & 0.5 \\
Boneless barbacoa meat & $\mathrm{kg} /$ carcass & 13.6 & 1.2 \\
Bones cooked in barbacoa & $\mathrm{kg} /$ carcass & 2.2 & 0.4 \\
Viscera in barbacoa (pancita) & $\mathrm{kg}$ & 2.5 & 0.5 \\
Waste of viscera in barbacoa & $\mathrm{kg}$ & 2.8 & 0.4 \\
Liters of broth & Liters/carcass & 15.0 & 0.7 \\
Barbacoa contained in taco & $\mathrm{g}$ & 40.0 & 5.0 \\
Barbacoa in tacos & Tacos/kg & 25.0 & 5.2 \\
Barbacoa in tacos & Tacos/carcass & 341.1 & - \\
Pancita in tacos & Tacos/kg & 25.0 & 5.2 \\
Pancita in tacos & Tacos/sheep & 62.5 & - \\
Broth contained in the dish & $\mathrm{ml}$ & 0.50 & 55.0 \\
Yield in broth & Dishes/carcass & 30.0 & 6.2 \\
\hline
\end{tabular}

kilogram of barbacoa meat was calculated. In addition, the amount of broth per dish was calculated with a graduated test tube with a capacity of $500 \mathrm{ml}$ (Table 3).

Prices of carcass meat, costs and sale prices of barbacoa meat to the consumer

These data were obtained from the butchers and barbacoyeros. Also, the estimated production costs to produce $1 \mathrm{~kg}$ of meat under intensive finishing conditions; the cost of feeding and deworming were considered to produce $1 \mathrm{~kg}$ of live meat. Later, $15 \%$ per kilogram of the meat produced was added from other fixed variables and costs (Lara 2008) (Table 4).

Comparison of prices in each marketing level

This information was calculated from data of prices and coefficients of yield of uncooked and cooked meat (Table 5), which made it possible to obtain the equivalent value to the producer at entrance to in situ slaughter and of raw carcass meat, as well as cooked carcass and pancita to the consumer.

\section{Marketing margins}

The marketing margins were calculated from the difference between the sale price of the unit of product for each marketing agent and the payment made in the purchase of the amount equivalent to the sold unit. To calculate the absolute gross margins $(M)$ and total relative margins $(m)$, the expression of $\mathrm{M}=\mathrm{Pc}$ (price to final consumer) $-\mathrm{VEP}$ (equivalent value to the sheep producer) and $\mathrm{m}=(\mathrm{M} / \mathrm{Pc}) \times 100$ and was adapted to each step of the marketing process with the different prices. The obtained data were processed through a numerical matrix
Table 4 Production costs and sale price of raw and cooked meat

\begin{tabular}{|c|c|c|}
\hline Concept & Unit of measure & Value \\
\hline Sheep at start of fattening & $\mathrm{US} \$ / \mathrm{kg}$ & 2.2 \\
\hline Sheep for fattening & US\$/sheep & 83.4 \\
\hline Feed & US\$/kg & 0.4 \\
\hline Cost of feed per fattening period & US\$ & 17.9 \\
\hline Production cost calculated by producer & $\begin{array}{l}\mathrm{US} \$ / \mathrm{kg} \text { of live } \\
\text { meat }\end{array}$ & 2.5 \\
\hline Production cost calculated by producer & US\$/sheep & 20.6 \\
\hline Price of live slaughter & US\$/kg & 2.5 \\
\hline Price of live slaughter & US\$/sheep & 109.8 \\
\hline Cost of slaughter & US\$/sheep & 4.6 \\
\hline Price of cold carcass to the consumer & $\mathrm{US} \$ / \mathrm{kg}$ & 5.7 \\
\hline Price of viscera (raw pancita) to the consumer & US\$/unit & 10.0 \\
\hline Price of skin & US\$ & 6.5 \\
\hline Price for the four feet & US\$ & 1.9 \\
\hline Price of head & US\$ & 5.0 \\
\hline Cost of preparation and sale of barbacoa & US\$/kg & 10.5 \\
\hline Cost of preparation and sale of barbacoa & US\$/carcass & 224.8 \\
\hline Consumer price of barbacoa and pancita & US\$ $/ \mathrm{kg}$ & 21.5 \\
\hline $\begin{array}{l}\text { Consumer price of taco with barbacoa } \\
\text { and pancita }\end{array}$ & US\$/taco & 1.0 \\
\hline Consumer price of broth & US\$/dish & 1.0 \\
\hline
\end{tabular}

Exchange rate: \$MX13.0 US\$ (Sistema de Administración Tributaria)

created as database in the program Microsoft Excel, according to the methodology proposed by Caldentey (1979).

\section{Results and discussion}

Equivalent and relative value of the uncooked cold carcass (meat and by-products)

To produce $1.0 \mathrm{~kg}$ of carcass meat, 2.1 and $2 \mathrm{~kg}$ of live farm and live slaughter sheep were used (Table 6). These results were lower compared with the previous studies in wool sheep 2.3 and $2.1 \mathrm{~kg}$ (Mondragón-Ancelmo et al. 2012). When processing live sheep at slaughter to meat on the part of the butcher, $1.0 \mathrm{~kg}$ of cold carcass meat was obtained as main product and $1.0 \mathrm{~kg}$ as by-product (pancita, skin, feet, head), contrasted with wool sheep $1.0 \mathrm{~kg}$ of carcass meat and $1.1 \mathrm{~kg}$ of by-products (Mondragón-Ancelmo et al. 2012).

The value of cold carcass meat to the final consumer was US $\$ 5.7 / \mathrm{kg}$, and of the by-products US $\$ 5.7 / \mathrm{kg}$. Equivalent values were obtained from $2.7,2.7$, and US $\$ 5.7 / \mathrm{kg}$ of live farm sheep, live slaughter sheep, and cold carcass meat from the slaughter, respectively. The relative value of the cold carcass was $50.1 \%$, and of by-products $49.9 \%$. These results are related with the production period and sale of the product; 
Table 5 Price and yield coefficient of raw and cooked meat

\begin{tabular}{|c|c|c|c|}
\hline Concept & Initials & Unit of measure & Value \\
\hline Live farm price to the producer & Pp & $\mathrm{US} \$ / \mathrm{kg}$ & 2.5 \\
\hline Price at entrance to slaughter & PER & $\mathrm{US} \$ / \mathrm{kg}$ & 2.8 \\
\hline Price of carcass from slaughter & PSR & $\mathrm{US} \$ / \mathrm{kg}$ & 5.7 \\
\hline Price of carcass cooked & PCC & $\mathrm{US} \$ / \mathrm{kg}$ & 21.5 \\
\hline Price of pancita from slaughter & Ps & US\$/unit & 10.0 \\
\hline Price of pancita cooked & Psub & $\mathrm{US} \$ / \mathrm{kg}$ & 21.5 \\
\hline Weighted price of raw by-products (pancita, head, four feet, and skin) & Ppsub & US\$/unit & 5.9 \\
\hline Live price of sheep bought from producer & Po & $\mathrm{kg}$ & 45.8 \\
\hline Waste from transport of sheep to slaughter & MCT & $\%$ & 5.5 \\
\hline Weight of live sheep at entrance to slaughter & $\mathrm{P} 1$ & $\mathrm{~kg}$ & 43.3 \\
\hline Yield coefficient of carcass from slaughter & CRSR & $\%$ & 50.9 \\
\hline Waste of carcass from slaughter & MSR & $\%$ & 2.2 \\
\hline Yield coefficient of carcass cooked & CRB & $\%$ & 31.5 \\
\hline $\begin{array}{l}\text { Yield coefficient of raw by-products from slaughter } \\
\text { (pancita, skin, head, feet, bone) }\end{array}$ & RSR & $\%$ & 49.1 \\
\hline Yield coefficient of pancita cooked & CRPC & $\%$ & 5.1 \\
\hline Total yield coefficient of meat and pancita cooked & CRTC & $\%$ & 36.6 \\
\hline
\end{tabular}

at the end and beginning of the year, the prices of sheep meat increase due to the high demand and low supply, compared with the months of the middle of the year, when the supply is high and the demand of sheep meat is low; therefore, the prices tend to decrease. In addition, the wholesaler's price speculation can modify these values.

Equivalent and relative value of the cooked carcass meat and pancita

To obtain $1.0 \mathrm{~kg}$ of cooked meat, $2.7,2.9$, and $1.4 \mathrm{~kg}$ of live farm sheep, live slaughter sheep, and cold carcass meat are required (Table 7), respectively; similar results were reported in wool sheep 2.7, 2.9, and $1.3 \mathrm{~kg}$ (Mondragón-Ancelmo et al. 2012). When the cold carcass was processed into barbacoa, $0.9 \mathrm{~kg}$ of boned barbacoa meat was obtained as main product and $0.1 \mathrm{~kg}$ of cooked pancita contrasted with $0.8 \mathrm{~kg}$ of meat with bone and $0.2 \mathrm{~kg}$ of pancita (Mondragón-Ancelmo et al. 2012). The value of barbacoa meat to the final consumer was US\$18.6 $(0.9 \mathrm{~kg})$ and of pancita US\$3.0 $(0.1 \mathrm{~kg})$. The equivalent values of the live farm sheep was US\$6.3/kg, live sheep at slaughter in situ US\$6.5/kg, and of cold carcass meat US\$7.9/ $\mathrm{kg}$. The relative value of cold carcass meat to barbacoa was $86 \%$, and of the by-product in barbacoa was $14 \%$. These

Table 6 Equivalent and relative value of raw carcass meat

\begin{tabular}{|c|c|c|c|}
\hline Concept & Initials & Unit of measure & Value \\
\hline Live sheep at entrance to slaughter in situ required to obtain $1 \mathrm{~kg}$ of carcass meat $=1 / \mathrm{CRSR} \times 100$ & QCER & $\mathrm{kg}$ & 2.0 \\
\hline Live farm sheep required to obtain $1 \mathrm{~kg}$ of carcass meat $=(\mathrm{QCER} / 1-\mathrm{MCT}) \times 100$ & QCPR & $\mathrm{kg}$ & 2.1 \\
\hline \multicolumn{4}{|l|}{ Participation of the value of the meat } \\
\hline Main product $=(\mathrm{QCER} \times \mathrm{CRSR}) / 100$ & $\mathrm{~K}$ & $\mathrm{~kg}$ & 1.0 \\
\hline By-products $=($ QCER $\times$ RSR9 $) / 100$ & Ksub & $\mathrm{kg}$ & 1.0 \\
\hline \multicolumn{4}{|l|}{ Value of the meat } \\
\hline Carcass meat (main product) $=\mathrm{K} \times \mathrm{PSR}$ & VKpp & US\$ & 5.7 \\
\hline \multicolumn{4}{|l|}{ Value of the by-product } \\
\hline By-products $=$ Ksub $\times$ Ps & Vksub & US\$ & 5.8 \\
\hline \multicolumn{4}{|l|}{ Relative value } \\
\hline$(\mathrm{VKpp} /(\mathrm{VKpp}+\mathrm{Vksub}) \times 100$ & VR & $\%$ & 50.1 \\
\hline \multicolumn{4}{|l|}{ Equivalent value } \\
\hline To the producer $=(\mathrm{QCPR})(\mathrm{Pp})(\mathrm{VRC}) / 100$ & VEP & $\mathrm{US} \$ / \mathrm{kg}$ & 2.7 \\
\hline To slaughter in situ $=(\mathrm{QCER})(\mathrm{PER})(\mathrm{VRC}) / 100$ & VEER & $\mathrm{US} \$ / \mathrm{kg}$ & 2.7 \\
\hline At exit from slaughter in situ = $(\mathrm{QCSR})(\mathrm{PSR})$ & VESR & $\mathrm{US} \$ / \mathrm{kg}$ & 5.7 \\
\hline
\end{tabular}


Table 7 Equivalent and relative value of the cooked meat

\begin{tabular}{|c|c|c|c|}
\hline Concept & Initials & Unit of measure & Value \\
\hline Live sheep at entrance to in situ slaughter needed to obtain $1 \mathrm{~kg}$ in barbacoa $=\mathrm{K} / \mathrm{CRTC} \times 100$ & QCER & $\mathrm{kg}$ & 2.7 \\
\hline Live farm sheep needed to obtain $1 \mathrm{~kg}$ in barbacoa $=(\mathrm{QCER} / 1-\mathrm{MCT}) / 100$ & QCPR & $\mathrm{kg}$ & 2.9 \\
\hline Cold carcass meat needed to obtain $1 \mathrm{~kg}$ of meat in barbacoa $=(\mathrm{QCER})(\mathrm{CRSR}) / 100$ & QCSR & $\mathrm{kg}$ & 1.4 \\
\hline \multicolumn{4}{|l|}{ Participation of the value of the meat in barbacoa } \\
\hline Main product $=(\mathrm{QCER} \times \mathrm{CRB}) / 100$ & $\mathrm{~K}$ & $\mathrm{~kg}$ & 0.9 \\
\hline Pancita in barbacoa $=(\mathrm{QCER} \times \mathrm{CRPC}) / 100$ & Ksub & $\mathrm{kg}$ & 0.1 \\
\hline Amount of main product $=(\mathrm{QCER} \times \mathrm{CRB}) / 100$ & Kpp & $\mathrm{kg}$ & 0.9 \\
\hline \multicolumn{4}{|l|}{ Value of the meat } \\
\hline Main product $($ carcass in barbacoa $)=(\mathrm{PCC} \times \mathrm{Kpp})$ & VKpp & US\$ & 18.6 \\
\hline Pancita $=($ Ksub $\times$ Psub $)$ & Vksub & US\$ & 3.0 \\
\hline \multicolumn{4}{|l|}{ Relative value } \\
\hline$(\mathrm{VKpp} /(\mathrm{VKpp}+\mathrm{Vksub}) \times 100$ & VR & $\%$ & 86.1 \\
\hline \multicolumn{4}{|l|}{ Equivalent values } \\
\hline To the producer $=(\mathrm{QCPR})(\mathrm{Pp})(\mathrm{VRC}) / 100$ & VEP & $\mathrm{US} \$ / \mathrm{kg}$ & 6.3 \\
\hline At entrance to slaughter in situ $=(\mathrm{QCER})(\mathrm{PER})(\mathrm{VRC}) / 100$ & VEER & US\$/kg & 6.5 \\
\hline At exit from slaughter in situ = $(\mathrm{QCSR})(\mathrm{PSR})$ & VESR & $\mathrm{US} \$ / \mathrm{kg}$ & 8.0 \\
\hline
\end{tabular}

values can be maintained or increase in time due to the costs of the inputs for the elaboration and marketing of the barbacoa.

\section{Marketing margins of uncooked and cooked meat}

The absolute marketing margin of cold carcass meat and cooked meat was 3.1 and US $\$ 15.2 / \mathrm{kg}$ (Table 8). In relative terms, the producer received 47 and $29 \%$, the intermediaries 53 and $71 \%$ of the price paid by the final consumer per kilogram of cold carcass meat and cooked meat. Previous studies in wool sheep report $40 \%$, in cold carcass meat $60 \%$, and in cooked meat 26 and $74 \%$ (HernándezMartínez et al. 2013); in goats $47 \%$, in cold carcass $53 \%$, and in cooked meat 20 and $80 \%$ (Rebollar-Rebollar et al. 2007) for producers and intermediaries.
The low marketing margin received by the producer in the current study was due to the fact that the producer had no knowledge of the demand of the market of the stockers and barbacoa sellers. In respect to which characteristics of sheep meat quality are required, under what conditions they should be produced, when is the adequate time to produce and sell the product and what quantity to produce to satisfy the demand, and which agent the product should be sold to in order to receive greater margin. This lack of knowledge, along with the price speculation on the part of the intermediaries, limits the producer from receiving a greater marketing margin of the product (Rodríguez et al. 1993). Most of the services could be improved in benefit of the consumers and the producers, if the producer knew the expectations of quality according to the demands of the market, and it would also make it possible to reduce the costs of production and marketing.

Studies carried out in other countries, such as Pakistan, indicated that the participation of the marketing services of
Table 8 Marketing margins of uncooked and cooked meat

\begin{tabular}{|c|c|c|c|c|}
\hline \multirow[t]{2}{*}{ Concept } & \multicolumn{2}{|l|}{ Uncooked } & \multicolumn{2}{|l|}{ Cooked } \\
\hline & $\begin{array}{l}\text { Absolute, } \\
\text { US\$/kg }\end{array}$ & Relative, $\%$ & $\begin{array}{l}\text { Absolute, } \\
\text { US\$/kg }\end{array}$ & Relative, $\%$ \\
\hline 1. Equivalent value to the producer & 2.7 & 46.5 & 6.3 & 29.3 \\
\hline 2. Equivalent value to the stocker & 2.7 & 47.9 & 6.5 & 30.2 \\
\hline 3. Equivalent value to the butcher & 5.7 & 100.0 & 7.9 & 36.7 \\
\hline 4. Gross margin of stocking of sheep (2-1) & 0.1 & 1.4 & 0.2 & 0.9 \\
\hline 5. Gross margin of transformation of sheep (3-2) & 3.0 & 52.1 & 1.4 & 6.5 \\
\hline 6. Gross margin of marketing $(7-1)$ & 3.1 & 53.5 & 15.2 & 70.7 \\
\hline 7. Price paid by the final consumer & 5.7 & 100.0 & 21.54 & 100.0 \\
\hline
\end{tabular}


Fig. 1 Benefit/cost ratio of the marketing margins for each agent

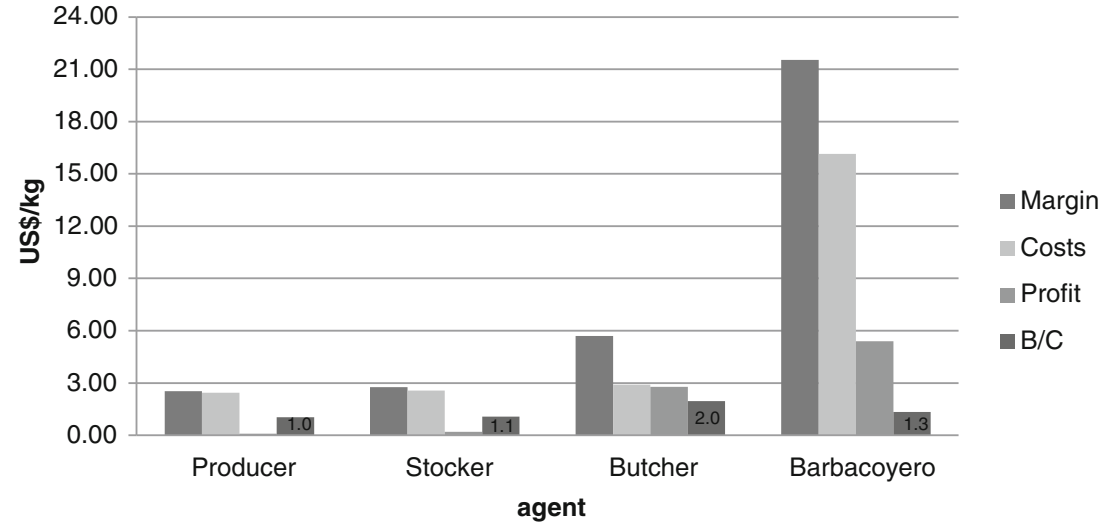

sheep and goats represents 32 and $30 \%$ for the intermediaries and the rest for the producer (Mahmood and Rodríguez 1993). Abbott (1987) reported similar results in sheep meat, 64 and $36 \%$; in beef, 66 and $34 \%$; and in pork, 75 and $25 \%$ for producers and intermediaries, respectively. These results are attributed to the fact that the productive chains of sheep, beef, and pork had an organization for the marketing of the final product.

Costs, profit, and benefit/cost ratio of uncooked and cooked meat

The income received by each agent for the sale of $1 \mathrm{~kg}$ of sheep meat was as follows: producer (US\$2.5 for the sale of a kilogram live farm sheep), stocker (US\$2.8 for the sale of a sheep at slaughter), butcher (US\$5.7 for the sale of a kilogram cold carcass meat), and barbacoa seller (US\$21.5 in the sale of barbacoa). Of these incomes, production cost and profit for the producer was US\$2.5/kg (96\%) and US\$9.0/kg (4\%), stocker US\$2.6/kg (93\%) and US\$0.2 (7\%), butcher US\$2.9/ $\mathrm{kg}(51 \%)$ and US\$2.8 (49\%), and for the barbacoa seller US\$16.1/kg (75\%) and US\$5.4/kg (25\%). The butcher obtained the best $\mathrm{B} / \mathrm{C}$ ratio, followed by the barbacoa seller, stocker, and producer finally (Fig. 1).

The $\mathrm{B} / \mathrm{C}$ kilogram ratio of meat obtained by the butcher was due to the fact that not only did he sell the carcass meat, but also pancita, head, feet, and skin, and his production costs were low compared with those of the barbacoa seller and the producer. The low $\mathrm{B} / \mathrm{C}$ ratio to the producer is attributed to the high cost of the cereals that were used in the animal feeding, which contributed to the increase of production costs of $1 \mathrm{~kg}$ of live meat (Lupton et al. 2007), added to price speculation on the part of the intermediaries (Mondragón-Ancelmo et al. 2012). Therefore, it is necessary to find other alternatives of production that minimize the cost of feed (Braga et al. 2011), to produce more than $60 \%$ of the inputs (Martínez-González et al. 2011), and shorten the marketing channels that induce a higher $\mathrm{B} / \mathrm{C}$ for the producer, and allow an increased profitability of sheep production systems.

\section{Conclusions and recommendations}

The best marketing channels used by the producer were producer-stocker-processers (butcher and barbacoa seller). The best marketing margin was for the intermediaries followed by the producer. The highest $\mathrm{B} / \mathrm{C}$ kilogram ratio of meat was for the butcher, barbacoa seller, stocker, and producer. It is recommended that the producer markets his/her product directly to the processors (butcher and barbacoa seller). Additionally, if the producer has the economic resources, along with having, or acquiring knowledge, he/she can perform the processing of his/her own product, such as in primary and secondary cuts for direct sale to restaurants or to the final consumer. However, for this purpose, a detailed and in depth market study is required to document the tastes and preferences of final consumers in the region of influence of sheep meat.

Acknowledgments Financial support of CONACYT (National Council of Science and Technology) is gratefully acknowledged, along with the active participation of farmers.

Conflict of interest All authors declare that there are no present or potential conflicts of interest among the authors and other people or organizations that could inappropriately bias their work.

\section{References}

Abbott, J.C., 1987. Mejora del mercadeo en el mundo en desarrollo. Colección FAO: Desarrollo económico y social, 37.

Braga, L.R.N., Costa, P.I.D., Facó, O. and Margaret, McM.C., 2011. Economic values for production traits of Morada Nova meat sheep in a pasture based production system in semi-arid Brazil, Small Ruminant Research, 96, 93-100.

Caldentey, A.P., 1979. Comercialización de productos Agropecuarios. Editorial Agrícola Española. Capítulo VII. pp. 108.

Cochran, W.G., 1984. Técnicas de muestreo. Ed. C.E.C.S.A, México. pp. 513.

Hernández-Martínez, J., Ortíz-Rivera, M.I., Rebollar-Rebollar, S., Guzmán-Soria, E. and González-Razo, F.J., 2013. Comercialización de ovinos de pelo en los municipios de 
Tejupilco y Amatepec del Estado de México, Agronomía Mesoamericana, 24, 195-201

Lara, P.S.J., 2008. Engorda de corderos con dietas a base de granos, altas en energía. Fortalecimiento del sistema producto ovino, México. pp. 26-31.

Lupton, C.J., Hustona, J.E., Craddock, B.F., Pfeiffer, F.A. and Polkb, W.L., 2007. Comparison of three systems for concurrent production of lamb meat and wool, Small Ruminant Research, 72, 133-140.

Mahmood, K. and Rodríguez, A., 1993. Marketing and processing of small ruminants in highland Balochistan Pakistan, Small Ruminant Research, 10, 93-102.

Martínez-González, E.G., Muñoz-Rodríguez, M., García-Muñiz, J.G., Santoyo-Cortés, V.H., Altamirano-Cárdenas, J.R. and RomeroMárquez, C., 2011. El fomento de la ovinocultura familiar en México mediante subsidios en activos: lecciones aprendidas, Agronomía Mesoamericana, 22, 367-377.
Mondragón-Ancelmo, J., Domínguez-Vara, I.A., Rebollar-Rebollar, S., Bórquez-Gastélum, J.L., Hernández-Martínez, J., 2012. Margins of sheep meat marketing in Capulhuac, State of Mexico, Tropical and Subtropical Agroecosystems, 15, 105-116.

Rebollar-Rebollar, S., Hernández-Martínez, J., García-Salazar, J.A., García-Mata, R., Torres-Hernández, G., Bórquez-Gastélum, J.L., Mejía-Hernández, P., 2007. Canales y márgenes de comercialización de caprinos en Tejupilco y Amatepec, México, Agrociencia, 41, 363 370.

Rodríguez, A., Ali, I., Afzal, M. and Shah, NA., 1993. Marketing of goat and sheep skins in highland Balochistan, Pakistan, Small Ruminant Research, 12, 259-270.

Teferra, K.B., Girma, H. A. and Abdu, E. J. 2011. Determinants of sheep prices in the highlands of northeastern Ethiopia: implication for sheep value chain development, Tropical Animal Health and Production, 43, 1525-1533. 